\title{
The Effects of Postplanting Environment on the Incidence of Soilborne Viral Diseases in Winter Cereals
}

\author{
L. Cadle-Davidson and G. C. Bergstrom
}

Department of Plant Pathology, Cornell University, Ithaca, NY 14853.

Current address of L. Cadle-Davidson: U.S. Department of Agriculture-Agricultural Research Service, Plant Genetic Resources Unit, Cornell University, Geneva, NY 14456.

Accepted for publication 20 January 2004.

\begin{abstract}
Cadle-Davidson, L., and Bergstrom, G. C. 2004. The effects of postplanting environment on the incidence of soilborne viral diseases in winter cereals. Phytopathology 94:527-534.

Soilborne wheat mosaic virus (SBWMV) and Wheat spindle streak mosaic virus (WSSMV) are putatively transmitted to small grains by the obligate parasite Polymyxa graminis, but little is known about environmental requirements for transmission and the resulting disease incidence. We planted susceptible wheat and triticale cultivars in field nurseries on different autumn dates in 3 years and observed the incidence of symptomatic plants in each following spring. Autumn postplanting environment explained most of the variation in disease caused by both viruses. Little apparent transmission, based on eventual symptom development, of either virus occurred after the average soil temperature dropped below $7^{\circ} \mathrm{C}$ for the remainder of the winter. To forecast disease, we tested an SBWMV transmission model in the field, based on laboratory results, that predicts opportunities for transmission based on soil temperature and soil moisture being simultaneously conducive. This model was predictive of soilborne wheat mosaic in 2 of 3 years. Zoospores of $P$. graminis have optimal activity at temperatures similar to those in the SBWMV transmission
\end{abstract}

ABSTRACT

Soilborne wheat mosaic virus (SBWMV) and Wheat spindle streak mosaic virus (WSSMV) commonly cause disease and yield loss in autumn-sown cereals $(5,8,9)$. Both viruses are presumed to be transmitted by the obligate parasite Polymyxa graminis, which can survive in dry soil without a host for at least 10 years while remaining viruliferous (1). The complexity of soil ecology, the obligate parasitic nature of both the viruses and their vector, and the fact that vector infection of roots and virus transmission occur underground complicate experimentation such that the epidemiology of these two viruses is not well understood.

Several studies have investigated the environmental parameters for transmission of SBWMV, WSSMV, and related furoviruses and bymoviruses. Using suspensions of zoospores to infect barley (Hordeum vulgare), Adams and Swaby (2) showed that $P$. graminis required $3 \mathrm{~h}$ at $15^{\circ} \mathrm{C}$ for attachment and host penetration to occur. Brakke et al. (3) had previously shown that SBWMV transmission from zoospore suspensions could occur within $24 \mathrm{~h}$ at temperatures ranging from 5 to $25^{\circ} \mathrm{C}$. By periodically transplanting seedlings from infested soil into sterile soil, Slykhuis (12) showed that WSSMV transmission could occur within 16 days at temperatures ranging from 7.5 to $17.5^{\circ} \mathrm{C}$, with up to $50 \%$ infection at $15^{\circ} \mathrm{C}$. Thermoperiodism between 5 to $15^{\circ} \mathrm{C}$ (night-day), however, resulted in WSSMV transmission of up to $96 \%$ (12), suggesting

Corresponding author: G. C. Bergstrom; E-mail address: gcb3@ cornell.edu

Publication no. P-2004-0324-01R

(c) 2004 The American Phytopathological Society model. Furthermore, the matric potential threshold (as it relates to waterfilled pore sizes) in the SBWMV transmission model fits well with $P$. graminis as vector given the size restrictions of $P$. graminis zoospores. Conditions optimal for SBWMV transmission in the laboratory were not conducive for WSSMV transmission in the laboratory or for wheat spindle streak mosaic development in the field. This differential response to environment after emergence, as indicated by disease symptoms, may be due to virus-specific environmental conditions required to establish systemic infection via the same vector. Alternatively, the differential response may have been due to the involvement of a different vector in our WSSMV nursery than in our SBWMV nursery. Our results suggest that, as a control tactic for SBWMV or WSSMV, earliness or lateness of planting is less important in determining virus transmission and disease than the specific postplanting environment. Improved models based on the postplanting environment might predict virus-induced losses of yield potential, and in some cases, growers might avoid purchase of spring inputs such as pesticides and fertilizer for fields with greatly reduced yield potential.

Additional keywords: Bymovirus, Furovirus, Wheat soilborne mosaic virus.

that environmental fluctuation stimulates WSSMV transmission. Environmental fluctuation has not been shown to have a role in SBWMV transmission.

Soil matric potential can affect soilborne virus transmission. Recently, we used an air pressure apparatus to develop and test a model for SBWMV transmission in which soil temperature and soil matric potential could explain most of the variation in number of plants infected (4). The model predicted that for SBWMV transmission to occur both soil temperature and soil moisture must be simultaneously conducive for at least $24 \mathrm{~h}$ at or following seedling emergence. Soil moisture appeared to work like a light switch, with all matric potentials equal to or greater than $-20 \mathrm{kPa}$ (wetter than field capacity) being conducive and the driest matric potential tested $(-40 \mathrm{kPa})$ being nonconducive (4). Soil temperature was a continuous variable, with the optimum temperature for transmission being $15^{\circ} \mathrm{C}$ and the coldest temperature tested that was still conducive for SBWMV transmission being $8^{\circ} \mathrm{C}$. Soil temperatures above $20^{\circ} \mathrm{C}$, while conducive for SBWMV transmission, are rarely encountered after planting winter wheat in New York.

One of the most important aspects of the SBWMV transmission model is that no significant transmission occurs at or below $6.5^{\circ} \mathrm{C}$, suggesting that in temperate climates SBWMV is either transmitted in the autumn or in the spring, but not during the winter months. Given the duration required for SBWMV systemic movement and symptom expression and the brevity of spring temperatures conducive to SBWMV symptom expression, spring infections by $P$. graminis are not likely to contribute to viral 
symptom expression. Because at least 24 consecutive conducive hours are required for significant SBWMV transmission to occur under New York conditions, there are relatively few windows for SBWMV transmission between the time that roots are available for infection and the time that soil temperature is too cold for transmission. Suboptimal soil temperature or nonconducive moisture in the autumn results in less efficient transmission and could result in lower incidence of symptom expression the following spring (4). Cool weather in the spring promotes the development and maintenance of symptom severity.

The air pressure apparatus was also used to study WSSMV transmission. Unexpectedly, the same experimental procedures, as well as modifications of the procedures for cooler and longer replication periods, did not result in detectable WSSMV transmission (4). Two possible explanations for the lack of WSSMV transmission are that WSSMV was unable to establish infection at $15^{\circ} \mathrm{C}$ or that another vector with different environmental requirements may be involved.

To validate the SBWMV transmission model as a predictor of soilborne wheat mosaic (SBWM) in the field, determine whether it fits for wheat spindle streak mosaic (WSSM) as well, and evaluate other predictors for SBWM and WSSM, we conducted a planting date study, the results of which are presented here. With 12 planting dates across a 6-week period, the experiments were designed to have enough temporal resolution to detect the effect of subtle environmental differences after planting on the incidence of viral symptoms in the following spring.

\section{MATERIALS AND METHODS}

Experimental design. The planting date experiments were planted by hand and hoe at an approximate depth of $5 \mathrm{~cm}$ with three replications of $1 \mathrm{~m}$ single rows. We used untreated seed and provided no supplemental water. Twelve planting dates were selected between 15 September and 1 November.

The SBWMV nursery (Conesus gravelly silt loam soil) in Trumansburg, NY, has been planted to winter wheat continuously from 1997 to 2002 and has expressed natural incidence of SBWMV symptoms in each year. Out of 24,610 stems assessed for soilborne virus symptoms in the SBWMV nursery in spring 2001, 2002, and 2003, only three stems had WSSMV symptoms. For all years, treatments were planted in a modified Latin square design with the 12 planting date treatments in three replications or blocks. For the first year of the study (2000 to 2001), the blocks were adjacent to each other in the field. However, SBWM had an aggregated distribution in our nursery, so in the last two growing seasons of the study (2001 to 2002 and 2002 to 2003), the blocks were dispersed across the field in a spatially balanced design, intermingled with resistance assessment experiments (Cadle-Davidson, L., Gray, S. M., Sorrells, M. E., and Bergstrom, G. C., unpublished data). 'Harus' wheat was planted in all 3 years of the study, and 'Presto' triticale was planted in the last 2 years of the study.

The WSSMV nursery (Williamson very fine sandy loam soil) in Caldwell Field, Ithaca, NY, has been planted to winter wheat continuously for 2 decades and has expressed natural incidence of WSSM in the absence of SBWM. WSSM incidence was uniform across the nursery, and blocks were planted adjacent to each other in the nursery in a modified Latin square design of 12 planting date treatments and three replications. 'Pioneer 2548' wheat was planted in all 3 years of the study.

In early May, during peak symptom expression for each virus (which typically occurs several days earlier for WSSMV than for SBWMV), leaves were collected, transported to an illuminated laboratory setting, randomized, subsampled, and assessed for viral incidence. In 2001, incidence was based on leaves on 30 stems per replicate. In 2002 and 2003, leaves on 40 stems per replicate were scored for improved statistical resolution.
Weather data and predicted incidence. Soil temperature data were collected at the Ithaca weather station on Game Farm Road, which is less than $1 \mathrm{~km}$ from the WSSMV nursery, and approximately $10 \mathrm{~km}$ from the SBWMV nursery. Four-inch soil temperature was chosen to be more biologically significant for autumn transmission than 8-in. soil temperature, which also was available from the weather station. Soil matric potential data were collected from two Watermark soil moisture probes located $7 \mathrm{~m}$ apart within each nursery and were recorded with WatchDog data loggers (Spectrum Technologies, Plainfield, IL).

The SBWMV transmission model is based on a study that resulted in greater than $80 \%$ transmission at $-20 \mathrm{kPa}$, but only a baseline transmission incidence of $14 \%$ at $-40 \mathrm{kPa}$ (4). The effect of matric potentials between -20 and $-40 \mathrm{kPa}$ on SBWMV transmission is unknown. For the purpose of this study, we selected $-25 \mathrm{kPa}$ as a cut-off such that days averaging drier soil matric potential are predicted by the model to have the baseline transmission incidence of $14 \%$. At $-25 \mathrm{kPa}$, the largest pore filled with water has a diameter of $11.8 \mu \mathrm{m}$, versus 14.7 and $7.4 \mu \mathrm{m}$ for -20 and $-40 \mathrm{kPa}$, respectively. Zoospores of plasmodiophorids related to $P$. graminis range in size from 3 to $6 \mu \mathrm{m}$ and the whiplash flagellum extends an additional $15 \mu \mathrm{m}$.

For days averaging $-25 \mathrm{kPa}$ or wetter, the average 4-in. soil temperature was entered into the statistical model reported by Cadle-Davidson et al. (4) and here is based on 24-h windows for simplicity: $\ln ($ odds of infection $)=-3.5383+0.2971 \times$ temperature $-0.00828 \times$ temperature $^{2}$. Because the percent incidence in wet soils at $6.5^{\circ} \mathrm{C}$ was not different from the baseline incidence in dry soils at any temperature (4), and because the parabolic model extrapolates artificially lower incidences for temperatures below $6.5^{\circ} \mathrm{C}$, all temperatures equal to or less than $6.5^{\circ} \mathrm{C}$ and all matric potentials drier than $-25 \mathrm{kPa}$ were stipulated to have the baseline transmission incidence of $14 \%$.

We observed the emergence date for many of the planting dates. To represent when plants likely emerged for unobserved planting dates, we estimated the emergence date using the following formula: emergence $=$ planting date $+7+(1 \ldots 12)$, where $(1 \ldots 12)$ is the planting date number in the overall series. This formula provides a good estimate for those planting dates for which we were able to monitor emergence, and we expect that it is a good predictor for all other planting dates as well.

Statistical analysis. Logistic regression models were developed for the number of symptomatic plants divided by the total and were analyzed using Proc Logistic in SAS (SAS Institute, Cary, NC). Data from the 2000 to 2001 WSSMV trial were not entered into the model because no symptoms were detected. Each conducive window predicted by the SBWMV transmission model was a fixed effect labeled $\mathrm{A}$ through $\mathrm{V}$, and the number of days each planting date experienced the window was entered for the predictor. The other factors in the model included the date of "emergence," represented as the number of days after 31 August; "emergence 2 " to account for the nonlinear decline in incidence for late planting dates that had less time to establish infections; the "temperature" at emergence; the categorical predictor "cultivar" to account for differences between 'Harus' wheat and 'Presto' triticale for SBWMV; the categorical predictor "virus," with WSSMV being the baseline virus; and the 15 "block" replications that occurred with three per year per virus as categorical predictors. Finally, all possible interactions were entered into the model with the exception of those with block and cultivar, because we wanted instead to look specifically for interactions with virus, which block and cultivar encompass. Finally, backward stepwise variable selection was conducted in Proc Logistic and nonsignificant variables were removed at $\alpha=0.05$. Nonsignificant variables with significant higher order interactions were retained in the model.

Transplanting into the WSSMV nursery. In the autumn of 2002, seeds of 'Pioneer 2548' wheat were germinated in moist 
paper towels for 3 days, and 17 seedlings were planted into dried, sieved WSSMV-infested soil and maintained at $-60 \mathrm{kPa}$ or drier in a peat pot in a $22^{\circ} \mathrm{C}$ growth chamber until time for transplanting to the WSSMV nursery on the same date as planting dates in experiments described previously. Wheat plants develop normally at $-60 \mathrm{kPa}$ but viral transmission is unlikely to occur. We chose to use 20 -cm-deep peat pots so the roots would be minimally disturbed upon transplanting. At transplanting, the pots were cut and removed from the dry soil clump that resulted from watering dried, sieved soil, and the plants and surrounding soil were placed in a hole to match ground level. The transplanted soil was then watered with about $500 \mathrm{ml}$ of water to facilitate equilibration to the surrounding field moisture. We distributed the 35 peat pots across all 12 planting dates and with transplant treatments ranging from 3 days to 6 weeks old. At least one pot of 3-week-old transplants was assigned to each planting date. As a negative control, two pots were planted to germinated seedlings on 4 October, maintained at $-60 \mathrm{kPa}$ or drier in the growth chamber through the planting season, vernalized in a $4^{\circ} \mathrm{C}$ growth chamber, and transplanted to the field when the ground thawed. None of the plants from the negative control had WSSMV symptoms at sampling time.

\section{RESULTS}

Relevant weather information and resulting incidence. In 2000 to 2001, the 4-in. soil temperature was relatively cool throughout the autumn (Fig. 1A), hovering near or below the temperature threshold for SBWMV transmission predicted by our model, and thereby limiting the opportunities for viral transmis-
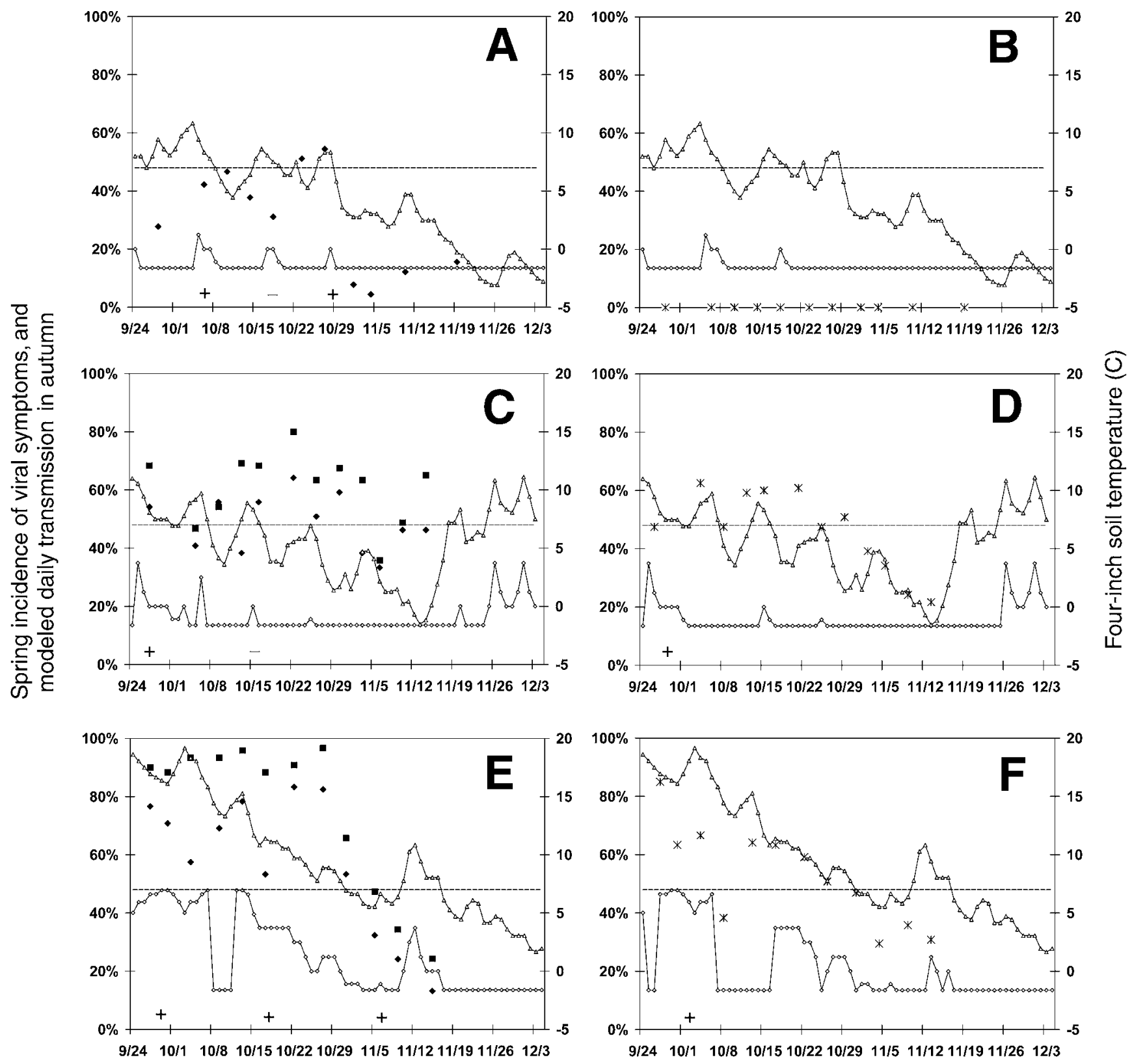

Fig. 1. Temperature, conducive windows, and resulting viral incidence. A, 2000 to 2001 Soilborne wheat mosaic virus (SBWMV); B, 2000 to 2001 Wheat spindle streak mosaic virus (WSSMV); C, 2001 to 2002 SBWMV; D, 2001 to 2002 WSSMV; E, 2002 to 2003 SBWMV; and F, 2002 to 2003 WSSMV. The figures display 4-in soil temperature (- - -) with a reference line for the cold-limit transmission threshold of $7^{\circ} \mathrm{C}(---)$; the modeled daily conduciveness based on the SBWMV transmission model $(-\diamond-)$, which takes into account soil temperature and soil matric potential; + if the conducive window is a positive predictor of incidence in the statistical analysis; - if the conducive window is a negative predictor of incidence; and the incidence of viral symptoms the following spring for each planting date on 'Harus' wheat (•), 'Presto' triticale (-), and 'Pioneer 2548' wheat (*), with the data point location on the $x$ axis corresponding with the estimated date of emergence. Both the $x$ and $y$ scales are the same for all figures. 
sion. Twenty days were warm enough for transmission, but only eight of these corresponded with sufficient moisture (Table 1). The incidence of SBWM that we observed the following spring reflected our transmission model's predictions. Plants from the first seven planting dates, which all experienced conducive environments for transmission, averaged $41.6 \%$ incidence; those that were planted after all conducive windows averaged just $8.8 \%$ incidence. Interestingly, plants from the first planting date had the lowest incidence of those from the first seven planting dates. The overall average SBWM incidence for 'Harus' wheat was $30.3 \%$.

Although we do not have a transmission model for WSSMV, we can infer that if it has the same vector as SBWMV, transmission might have similar requirements. For the 2000 to 2001 WSSMV nursery, only 6 days in autumn were conducive for transmission according to the SBWMV transmission model (Ta- ble 1). Temperatures in late April and early May 2001 were much hotter than normal with two warm spells averaging $6^{\circ} \mathrm{C}$ above normal over a total of 17 days. No WSSMV symptoms were observed in the spring of 2001 for any planting date (Fig. 1B).

The soil temperatures in 2001 to 2002 were strikingly similar to those in 2000 to 2001 until 18 November, when warm and wet conditions resulted in plants from all planting dates experiencing a conducive environment that lasted through the first week of December (Fig. 1C). Before this conducive window, there were 16 days warm enough for transmission, and 10 of those had sufficient moisture for transmission (Table 1). With exposure to nine more conducive days for transmission, the average SBWM incidence for 'Harus' jumped to $48.8 \%$ for all planting dates, and plants from all planting dates averaged at least $33 \%$ incidence. We added a second susceptible check, 'Presto' triticale, to our

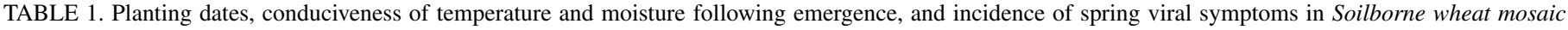
virus (SBWMV) and Wheat spindle streak mosaic virus (WSSMV) nurseries resulting from autumn virus transmission

\begin{tabular}{|c|c|c|c|c|c|c|}
\hline Experiment & Planting date & $\begin{array}{c}\text { Estimated } \\
\text { emergence date }\end{array}$ & $\begin{array}{c}\text { Number } \\
\text { of conducive } \\
\text { temperature days }\end{array}$ & $\begin{array}{c}\text { Number of conducive } \\
\text { moisture days before } \\
3 \text { December }\end{array}$ & $\begin{array}{c}\text { Number } \\
\text { of combined } \\
\text { conducive days }\end{array}$ & $\begin{array}{l}\text { Spring symptom } \\
\text { incidence }(\%)\end{array}$ \\
\hline \multirow[t]{11}{*}{ SBWMV 2000-01 'Harus' wheat } & $9 / 20$ & $9 / 28$ & 20 & 22 & 8 & 27.8 \\
\hline & $9 / 27$ & $10 / 6$ & 12 & 21 & 7 & 42.2 \\
\hline & $9 / 30$ & $10 / 10$ & 9 & 17 & 4 & 46.7 \\
\hline & $10 / 3$ & $10 / 14$ & 9 & 14 & 4 & 37.8 \\
\hline & $10 / 6$ & $10 / 18$ & 6 & 13 & 3 & 31.1 \\
\hline & $10 / 10$ & $10 / 23$ & 3 & 11 & 1 & 51.1 \\
\hline & $10 / 13$ & $10 / 27$ & 2 & 11 & 1 & 54.4 \\
\hline & $10 / 17$ & $11 / 1$ & 0 & 10 & 0 & 7.8 \\
\hline & $10 / 19$ & $11 / 4$ & 0 & 10 & 0 & 4.4 \\
\hline & $10 / 24$ & $11 / 10$ & 0 & 10 & 0 & 12.2 \\
\hline & $11 / 1$ & $11 / 19$ & 0 & 6 & 0 & 15.6 \\
\hline Average & & & 6 & 13 & 3 & 30.1 \\
\hline \multirow[t]{11}{*}{ WSSMV 2000-01 'Pioneer 2548' wheat } & $9 / 20$ & $9 / 28$ & 20 & 11 & 6 & 0.0 \\
\hline & $9 / 27$ & $10 / 6$ & 12 & 10 & 5 & 0.0 \\
\hline & $9 / 30$ & $10 / 10$ & 9 & 7 & 2 & 0.0 \\
\hline & $10 / 3$ & $10 / 14$ & 9 & 7 & 2 & 0.0 \\
\hline & $10 / 6$ & $10 / 18$ & 6 & 7 & 2 & 0.0 \\
\hline & $10 / 10$ & $10 / 23$ & 3 & 5 & 0 & 0.0 \\
\hline & $10 / 13$ & $10 / 27$ & 2 & 5 & 0 & 0.0 \\
\hline & $10 / 17$ & $11 / 1$ & 0 & 5 & 0 & 0.0 \\
\hline & $10 / 19$ & $11 / 4$ & 0 & 5 & 0 & 0.0 \\
\hline & $10 / 24$ & $11 / 10$ & 0 & 5 & 0 & 0.0 \\
\hline & $11 / 1$ & $11 / 19$ & 0 & 3 & 0 & 0.0 \\
\hline Average & & & 6 & 6 & 2 & 0.0 \\
\hline \multirow[t]{12}{*}{ SBWMV 2001-02 'Harus' wheat } & $9 / 19$ & $9 / 27$ & 28 & 32 & 19 & 54.2 \\
\hline & $9 / 26$ & $10 / 5$ & 20 & 25 & 12 & 40.8 \\
\hline & $9 / 29$ & $10 / 9$ & 17 & 24 & 11 & 55.8 \\
\hline & $10 / 2$ & $10 / 13$ & 17 & 24 & 11 & 38.3 \\
\hline & $10 / 4$ & $10 / 16$ & 14 & 23 & 10 & 55.8 \\
\hline & $10 / 9$ & $10 / 22$ & 13 & 21 & 10 & 64.2 \\
\hline & $10 / 12$ & $10 / 26$ & 12 & 17 & 9 & 50.8 \\
\hline & $10 / 15$ & $10 / 30$ & 12 & 15 & 9 & 59.2 \\
\hline & $10 / 18$ & $11 / 3$ & 12 & 15 & 9 & 38.3 \\
\hline & $10 / 20$ & $11 / 6$ & 12 & 13 & 9 & 33.3 \\
\hline & $10 / 23$ & $11 / 10$ & 12 & 11 & 9 & 46.3 \\
\hline & $10 / 26$ & $11 / 14$ & 12 & 10 & 9 & 46.3 \\
\hline Average & & & 14 & 18 & 10 & 48.6 \\
\hline \multirow[t]{12}{*}{ SBWMV 2001-02 'Presto' triticale } & $9 / 19$ & $9 / 27$ & 28 & 32 & 19 & 68.3 \\
\hline & $9 / 26$ & $10 / 5$ & 20 & 25 & 12 & 46.7 \\
\hline & $9 / 29$ & $10 / 9$ & 17 & 24 & 11 & 54.2 \\
\hline & $10 / 2$ & $10 / 13$ & 17 & 24 & 11 & 69.2 \\
\hline & $10 / 4$ & $10 / 16$ & 14 & 23 & 10 & 68.3 \\
\hline & $10 / 9$ & $10 / 22$ & 13 & 21 & 10 & 80.0 \\
\hline & $10 / 12$ & $10 / 26$ & 12 & 17 & 9 & 63.3 \\
\hline & $10 / 15$ & $10 / 30$ & 12 & 15 & 9 & 67.5 \\
\hline & $10 / 18$ & $11 / 3$ & 12 & 15 & 9 & 63.3 \\
\hline & $10 / 20$ & $11 / 6$ & 12 & 13 & 9 & 35.8 \\
\hline & $10 / 23$ & $11 / 10$ & 12 & 11 & 9 & 48.8 \\
\hline & $10 / 26$ & $11 / 14$ & 12 & 10 & 9 & 65.0 \\
\hline Average & & & 14 & 18 & 10 & 60.9 \\
\hline
\end{tabular}


SBWMV planting date trial in 2001 to 2002. 'Presto' is slightly more susceptible than 'Harus' and averaged $61.1 \%$ incidence across all planting dates.

The WSSMV nursery experienced similar though slightly drier conditions throughout autumn 2001 (Fig. 1D; Table 1). The overall average WSSM incidence for 'Pioneer 2548' wheat was 46.3\%. Plants from the first six planting dates experienced the three early conducive windows for transmission and averaged $56.3 \%$ incidence, with little variation from the group average. The last six planting dates experienced only the late autumn conducive window, and unlike SBWMV, these plants showed a linear decline in incidence as the date of emergence approached the final conducive window. This was our first evidence from this study that WSSMV transmission, as inferred from springtime disease incidence, may not follow our SBWMV transmission model.
The autumn of 2002 was significantly warmer and wetter than the previous two planting seasons. Forty-five days were warm enough for SBWMV transmission and only four of those days were not wet enough for transmission (Fig. 1E; Table 1). Our SBWMV transmission model predicts that all planting dates would have experienced conducive windows for transmission, though the last planting date only experienced the tail end of the final conducive window. The overall average SBWM incidence for 'Harus' wheat was $57.9 \%$ and for 'Presto' triticale was $75.7 \%$.

The WSSMV nursery was once again similar but drier than the SBWMV nursery, with 29 days predicted by the SBWMV model to have conducive soil moisture and temperature for transmission (Fig. 1F; Table 1). The overall average WSSM incidence for 'Pioneer 2548' wheat was $52.8 \%$. There was a linear decline in WSSM incidence with planting date that paralleled the decline in

TABLE 1. (Continued from preceding page)

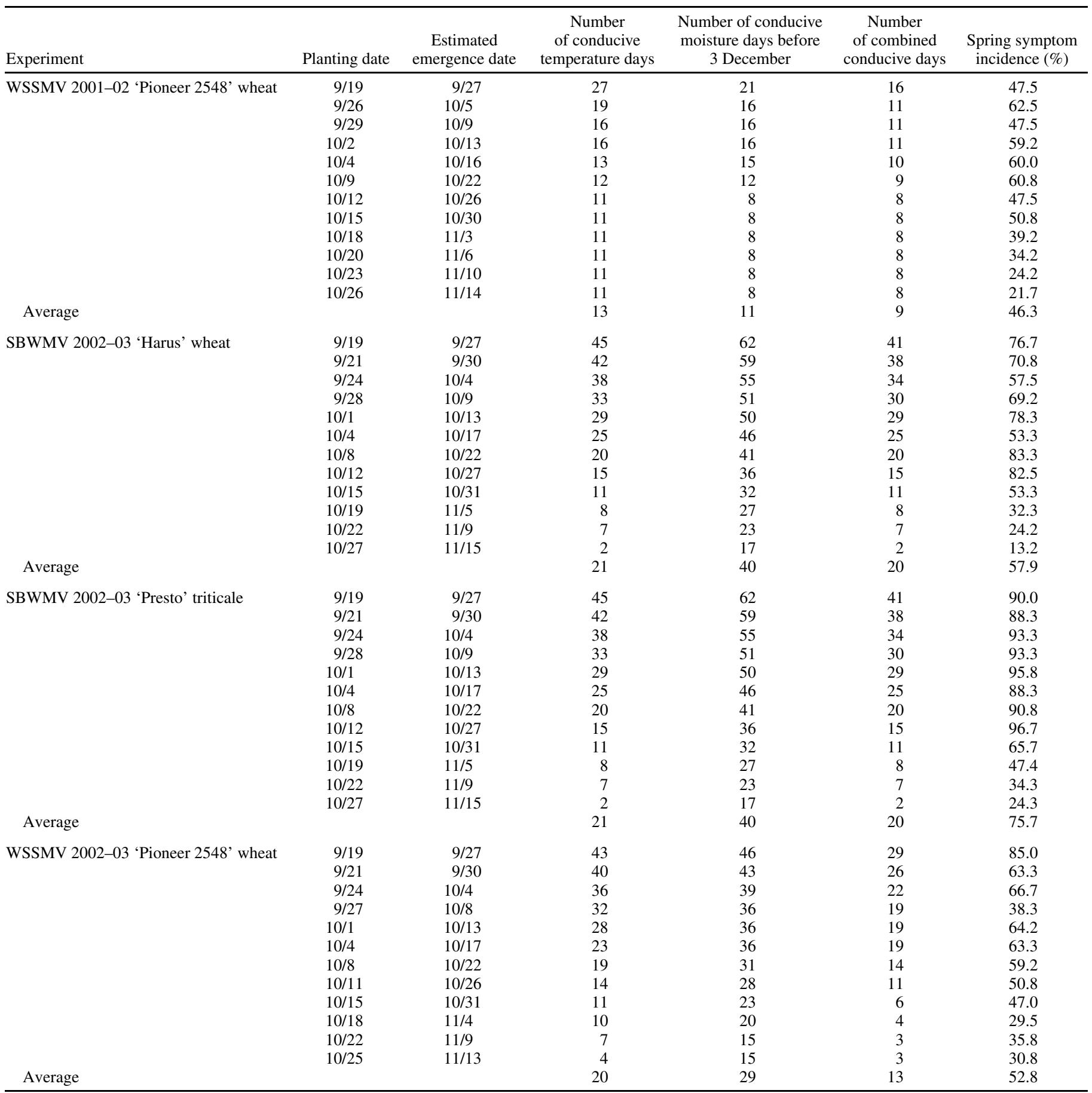


soil temperature. Interestingly, the fourth planting date emerged during a dry spell and averaged only $38.3 \%$ WSSM incidence compared with the other six of the first seven planting dates average of $66.9 \%$.

Statistical analysis of planting date. We analyzed a logistic model with 3 years of data for SBWMV and 2 years of data for WSSMV. Each conducive window predicted by the SBWMV transmission model was a categorical predictor, with the number of conducive days experienced after emergence entered for each planting date. Other variables of biological and experimental significance were selected and entered into a model with all possible interactions, and the entire model was subjected to backward stepwise variable selection, the results of which are shown in Table 2.

The fixed variable "block" explained most of the variation in the model, because block encompasses not only location within the nursery, which changed each year, but also the year and virus tested. Cultivar was, not surprisingly, a significant predictor of incidence, because 'Presto' triticale and 'Harus' wheat are not equally susceptible to SBWMV. Date of emergence was a secondorder polynomial (emergence ${ }^{2}$ ) that interacted with temperature at emergence. The estimate for emergence ${ }^{2} \times$ temperature was nega- $^{-}$ tive, reflecting the lower incidence for late planting dates, as well as the lower-than-expected incidence for the earliest planting dates. This statistical interaction along with the temperature information already contained in the conducive window predictors makes the significant, negative estimate for temperature at emergence difficult to explain biologically.

The conducive windows predicted by the SBWMV model (Fig. $1 \mathrm{~A}$ and $\mathrm{C}$ to $\mathrm{F}$, each peak marked with a plus or minus sign or blank for nonsignificance) should be positive predictors for inci- dence, and for the most part they were. Five of the seven conducive windows experienced in the SBWMV nursery in autumn of 2000 and 2002 were significantly positive predictors of SBWM incidence (Fig. 1A and E). For SBWMV in 2001 and for WSSMV in both years, only the first conducive window was a positive predictor for incidence, likely an artifact resulting from

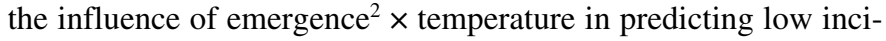
dence for early and late planting dates.

The fact that the SBWMV transmission model does not predict WSSM incidence as well as other predictors, such as emergence date and temperature at emergence, suggests that the two viruses have different requirements for transmission. Furthermore, the incidences of the two viruses respond differently to both the date of emergence and the 4-in. soil temperature at emergence, as shown by the significant interactions of virus with each of those predictors.

Transplanting into the WSSMV nursery. To determine whether the developmental stage of a wheat plant affects its susceptibility to WSSMV transmission, we designed a transplanting experiment whereby we started seedlings in a controlled environment nonconducive for WSSMV transmission. All ages of transplants, having experienced anywhere from 3 days to 6 weeks in the growth chamber, were susceptible to viral transmission upon transplanting (Fig. 2). The age of the transplants was a second-order predictor of WSSM incidence $(P=0.0096)$, reflected by the generality that 3 -week-old transplants had slightly higher WSSM incidence than either 3-day or 6-week-old transplants (Fig. 2). Although this was a significant effect, it has little meaning in the narrow window for transmission between planting and arrival of nonconducive cold temperatures.

TABLE 2. Logistic regression analysis of Soilborne wheat mosaic virus (SBWMV) and Wheat spindle streak mosaic virus (WSSMV) planting date factors

Analysis of maximum likelihood estimates

\begin{tabular}{|c|c|c|c|c|c|}
\hline \multirow[b]{2}{*}{ Parameter } & & & & & \\
\hline & df & Estimate & Standard error & Wald chi-square & $P>$ chi-square \\
\hline Intercept & 1 & 3.0383 & 1.5359 & 3.9135 & 0.0479 \\
\hline Block 2000-01 SBWMV 1 & 1 & -2.4686 & 0.2359 & 109.5050 & $<0.0001$ \\
\hline Block 2000-01 SBWMV 2 & 1 & -1.4985 & 0.2096 & 51.1312 & $<0.0001$ \\
\hline Block 2000-01 SBWMV 3 & 1 & -0.2657 & 0.1850 & 2.0623 & 0.1510 \\
\hline Block 2001-02 SBWMV 1 & 1 & -0.9383 & 0.1656 & 32.1165 & $<0.0001$ \\
\hline Block 2001-02 SBWMV 2 & 1 & 0.7747 & 0.1533 & 25.5351 & $<0.0001$ \\
\hline Block 2001-02 SBWMV 3 & 1 & 1.7880 & 0.1562 & 131.0820 & $<0.0001$ \\
\hline Block 2001-02 WSSMV 1 & 1 & 0.7645 & 0.1983 & 14.8628 & 0.0001 \\
\hline Block 2001-02 WSSMV 2 & 1 & 0.7464 & 0.1983 & 14.1742 & 0.0002 \\
\hline Block 2001-02 WSSMV 3 & 1 & 0.6742 & 0.1982 & 11.5719 & 0.0007 \\
\hline Block 2002-03 SBWMV 1 & 1 & -0.1799 & 0.2021 & 0.7922 & 0.3734 \\
\hline Block 2002-03 SBWMV 2 & 1 & 0.2997 & 0.2021 & 2.1989 & 0.1381 \\
\hline Block 2002-03 SBWMV 3 & 1 & -0.1752 & 0.2070 & 0.7164 & 0.3973 \\
\hline Block 2002-03 WSSMV 1 & 1 & 0.0542 & 0.1371 & 0.1565 & 0.6924 \\
\hline Block 2002-03 WSSMV 2 & 0 & 0 & $\ldots$ & $\ldots$ & $\ldots$ \\
\hline Cv. Harus & 1 & 0.5375 & 0.3076 & 3.0530 & 0.0806 \\
\hline Cv. Presto & 1 & 1.4242 & 0.3105 & 21.0376 & $<0.0001$ \\
\hline SBWMV & 0 & 0 & $\ldots$ & $\ldots$ & $\ldots$ \\
\hline Temperature & 1 & -0.9652 & 0.1632 & 34.9700 & $<0.0001$ \\
\hline Emergence & 1 & -0.0697 & 0.0543 & 1.6496 & 0.1990 \\
\hline Emergence $\times$ SBWMV & 1 & -0.0157 & 0.0055 & 8.2637 & 0.0040 \\
\hline Temperature $\times$ SBWMV & 1 & -0.0647 & 0.0169 & 14.6976 & 0.0001 \\
\hline Emergence $\times$ emergence & 1 & 0.0002 & 0.0005 & 0.1521 & 0.6965 \\
\hline Emergence $\times$ emergence $\times$ temperature & 1 & -0.0003 & 0.0001 & 27.7689 & $<0.0001$ \\
\hline Emergence $\times$ temperature & 1 & 0.0357 & 0.0063 & 31.9062 & $<0.0001$ \\
\hline SBWMV 2000-01 window $\mathrm{A}^{\mathrm{a}}$ & 1 & 0.1554 & 0.0766 & 4.1196 & 0.0424 \\
\hline SBWMV 2000-01 window B & 1 & -0.3157 & 0.0896 & 12.4083 & 0.0004 \\
\hline SBWMV 2000-01 window C & 1 & 1.8084 & 0.2794 & 41.8947 & $<0.0001$ \\
\hline SBWMV 2001-02 window D & 1 & 0.1851 & 0.0353 & 27.4546 & $<0.0001$ \\
\hline SBWMV 2001-02 window F & 1 & -0.8091 & 0.1939 & 17.4108 & $<0.0001$ \\
\hline WSSMV 2001-02 window J & 1 & 0.1323 & 0.0573 & 5.3268 & 0.0210 \\
\hline SBWMV 2002-03 window N & 1 & 0.2393 & 0.0395 & 36.6546 & $<0.0001$ \\
\hline SBWMV 2002-03 window O & 1 & 0.0543 & 0.0125 & 18.8554 & $<0.0001$ \\
\hline SBWMV 2002-03 window P & 1 & 0.6293 & 0.2158 & 8.5050 & 0.0035 \\
\hline WSSMV 2002-03 window R & 1 & 0.4600 & 0.0509 & 81.6702 & $<0.0001$ \\
\hline
\end{tabular}

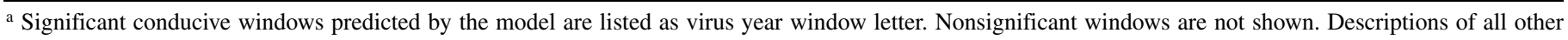
predictors are explained in the text. 
Trends that appeared in the 2002 to 2003 planting date experiment for WSSMV were reflected in the transplanting experiment. Particularly striking was the low incidence for planting date four in both experiments (Figs. 1F and 2). This suggests that regardless of age, the conditions soon after exposure to autumn soil environment are critical to the development of WSSMV symptoms the following spring. The negative control for the experiment, two replicates that remained in nonconducive moistures through the autumn followed by vernalization in $4^{\circ} \mathrm{C}$ growth chambers and transplanted immediately at ground thaw in the spring, had no symptomatic plants. This strongly suggests not only that our experimental design limited transmission before transplanting but also that the most significant transmission events leading to symptom expression for 2002 to 2003 occurred in the autumn, or perhaps, the winter.

\section{DISCUSSION}

In a previous study, we used controlled environments to develop a logistic model for transmission of SBWMV, as detected in wheat roots using enzyme-linked immunosorbent assay. The model predicted that for SBWMV transmission to occur both soil temperature and soil moisture must be simultaneously conducive for at least $24 \mathrm{~h}$ at or following seedling emergence. While the SBWMV transmission model provided novel insight into the biology of SBWMV transmission and root infection, it provided little insight to the economically important aspects of the pathosystem in the field, namely symptom development and the incidence of disease.

In the current study, we planted small grains genotypes across 12 planting dates within a 6-week window in the autumn to determine whether minor variations in environment soon after emergence would result in significantly different incidences of disease symptoms the following spring. Plants from all planting dates emerged in the autumn and experienced predominantly the same winter and spring weather conditions. Thus, we hypothesized that any planting date effect on disease incidence would result from the minor variations in environment soon after emergence and not from variations during winter and spring, which all plants within a growing season experienced similarly. This study was done to determine whether the model for SBWMV transmission could also serve as a model for relative disease incidence in the field.

The results of the current study also provide strong circumstantial evidence that the most important transmission events for SBWMV and WSSMV occur in the autumn and that little transmission occurs after soil temperatures drop below $7^{\circ} \mathrm{C}$ for the duration of the winter. These conclusions are further supported by the results of our transplanting study in which negative control plants that were retained in nonconducive environments through the winter and transplanted to the field in early spring had no WSSMV symptoms. The negative control plants also supported our method for the transplanting study, because no significant transmission occurred prior to transplanting. The transplanting study itself showed that wheat plants from 3 days to 6 weeks old are all susceptible to WSSMV transmission, but that there is some optimal age for transmission.

Based on the results of our planting date study, we expected that this age would be very close to the age at emergence and that the susceptibility would decline rapidly with increasing age. This hypothesis is based on the simple observation that plants planted at the first planting dates experience all conducive windows for transmission, and thus, if there was no age-related susceptibility effect, plants from the first planting dates should have the highest incidence. They do not. In fact, we modeled the first nine planting dates for all years, representing planting dates typically recommended to wheat producers, and found that there was a significant $(P=0.02)$, mildly increasing slope for incidence over emer- gence date for both viruses (data not shown). Thus, even though the earliest sown crop experiences more days conducive for transmission than any other, our results predict that plants from the next eight planting dates all have greater likelihood for SBWMV or WSSMV transmission.

Notably, we were able to detect significant differences in planting dates as little as 2 days from one another for both viruses, suggesting that the soil environment immediately after planting or germination is important in predicting transmission incidence. This may not be an age-related effect, because we observed a significant drop in incidence of WSSM for the fourth planting date in 2002 to 2003, regardless of whether we planted seed or transplanted established plants. This leads to an untested hypothesis that the first exposure of roots to (new) field conditions, whether upon emergence or transplanting, somehow determines whether the resulting WSSM incidence will be relatively high or low.

For a planted seed, the first exposure to field conditions is by the three adventitious roots that emerge several days after planting. For our dry, transplanted soil clump, the first exposure to new field conditions occurs upon equilibration to the surrounding field temperature and moisture. Roots that had been struggling through the dry conditions, as yet remaining uninfected by WSSMV, now have sufficient moisture and, during the first few days, send out new root tips and lateral roots. The soil microfauna are now stimulated to act and are drawn to the rhizodepositions of either the germinated seedling or the tips and lateral root initials of the transplant. Our results suggest that this is the moment of greatest importance for successful viral transmission-the first interactions of the host with the vector and virus.

In this study, we tested in the field a SBWMV transmission model based on laboratory results (4), and the incidence of SBWM seemed to follow the model in most years. WSSM, however, responded to emergence date and temperature at emergence more strictly than to the SBWMV model. Studies using suspensions of $P$. graminis zoospores have revealed that $P$. graminis has

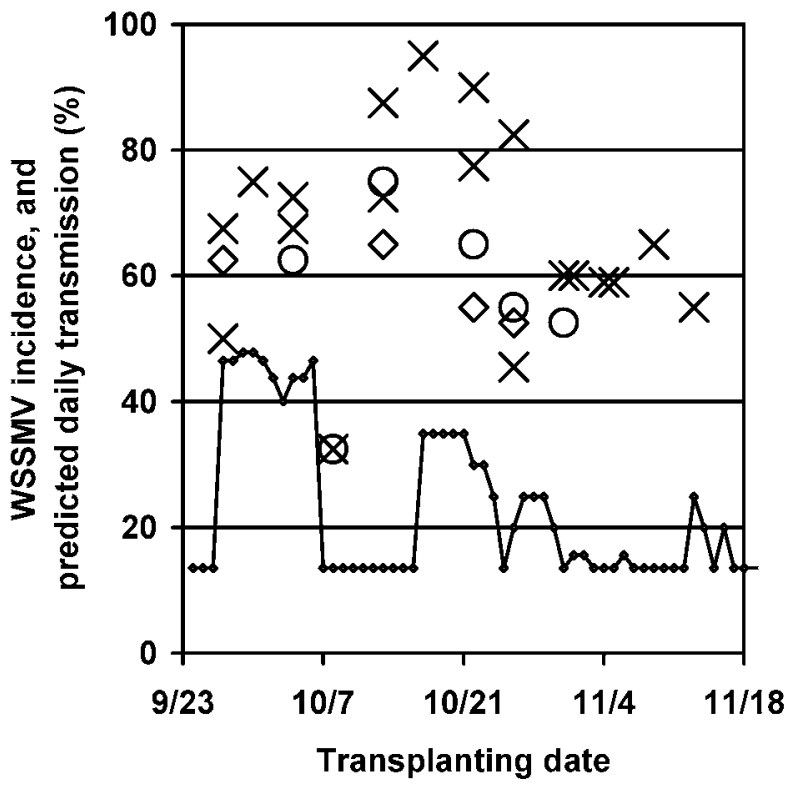

Fig. 2. The effect of age at first exposure to conducive field conditions on the susceptibility of wheat to Wheat spindle streak mosaic virus (WSSMV) transmission. The modeled daily conduciveness based on the Soilborne wheat mosaic virus (SBWMV) transmission model (--) is the same as that from Figure 1F $(-\diamond-)$. The incidence of viral symptoms for each transplanting date is plotted with a symbol representing the age of the transplant, 3 days $(\diamond)$, 3 weeks $(\times)$, or 6 weeks $(O)$. The location of the point along the $x$ axis corresponds with the estimated date of emergence for seeds that shared the planting date, to facilitate comparisons between Figures $1 \mathrm{~F}$ and 2. 
an optimal activity at temperatures similar to those in the SBWMV transmission model $(2,3,4)$, and it stands to reason that $P$. graminis also would have some minimal moisture requirement in order to swim to the host. As discussed by Cadle-Davidson et al. (4), the matric potential threshold in the SBWMV transmission model fits well with $P$. graminis as vector given the size restrictions of $P$. graminis zoospores.

The differential results may simply be a reflection of the different interactions of SBWMV and WSSMV with P. graminis and with small grains hosts. The pioneering studies of SBWMV and WSSMV transmission provided preliminary evidence that both viruses are transmitted by $P$. graminis $(10,11,13)$. However, the authors of those studies also point out the difficulty that they had in finding $P$. graminis in roots of field-grown wheat and state that the suspensions used in their transmission studies were contaminated with many other microorganisms $(11,13)$. Regardless of the caution with which the pioneering studies were presented, substantial correlative evidence linking $P$. graminis and numerous soilborne viruses exists, and the dogma that $P$. graminis is the only vector of both SBWMV and WSSMV is strong. However, a recent study of the correlation of Indian peanut clump virus and $P$. graminis (its presumed vector) provided convincing evidence (not discussed by the authors) that $P$. graminis is not required for transmission of members of the genus Furovirus to wheat and barley (6). It is tempting to speculate that the differential environmental requirements (both in a controlled environment [4] and in the current field study) observed for WSSMV and SBWMV are due to the activity of an alternate vector. Indeed, other organisms that are intimately associated with plant roots could possibly be involved in viral transmission in some environments. However, neither the current study nor the controlled environment study (4) were designed to investigate vector identity but instead focused on the environmental parameters required for virus transmission and disease incidence.

In the late 1960s, Gates (7) conducted a planting date study for WSSMV with three or four planting dates per year. The most significant planting date effect was a reduction in incidence by planting on or after 29 October. However, Gates noted that plants planted at these late dates grew to only 3 to $6 \mathrm{~cm}$ in height and suffered significant winter kill. Our results corroborate his findings that, while planting late in the season reduces the incidence of WSSM (and in most cases, of SBWM), the yield lost to winter injury and slow development overwhelms the gain from viral control. Among the generally recommended planting dates, we found that earliness or lateness of planting is less important in determining virus transmission than the specific postplanting environment. Models based on the postplanting environment might predict virus-induced losses of yield potential, and in some cases, growers might avoid purchase of inputs such as pesticides and fertilizer for fields with reduced yield potentials.

\section{ACKNOWLEDGMENTS}

This research was supported by Cornell University Hatch Project NYC153472, the New York State IPM Program, a fellowship to L. CadleDavidson from the Storkan-Hanes-McCaslin Research Foundation, and a graduate research assistantship to L. Cadle-Davidson from the Department of Plant Pathology, Cornell University, Ithaca, NY. We thank S. M. Gray for helpful discussions during the course of this research and for critically reviewing the manuscript, and W. T. Federer and J. Barnard for input on the statistical analyses.

\section{LITERATURE CITED}

1. Adams, M. J. 1990. Epidemiology of fungally-transmitted viruses. Soil Use Manage. 6:184-189.

2. Adams, M. J., and Swaby, A. G. 1988. Factors affecting the production and motility of zoospores of Polymyxa graminis and their transmission of Barley yellow mosaic virus (BaYMV). Ann. Appl. Biol. 112:69-78.

3. Brakke, M. K., Estes, A. P., and Schuster, M. L. 1965. Transmission of Soilborne wheat mosaic virus. Phytopathology 55:79-86.

4. Cadle-Davidson, L., Schindelbeck, R. R., van Es, H. M., Gray, S. M., and Bergstrom, G. C. 2003. Using air pressure cells to evaluate the effect of soil environment on the transmission of soilborne viruses of wheat. Phytopathology 93:1131-1136.

5. Cunfer, B. M., Demski, J. W., and Bays, D. C. 1988. Reduction in plant development, yield, and grain quality associated with Wheat spindle streak mosaic virus. Phytopathology 78:198-204.

6. Delfosse, P., Reddy, A. S., Devi, K. T., Legreve, A., Risopoulos, J., Doucet, D., Devi, P. S., Maraite, H., and Reddy, D. V. R. 2002. Dynamics of Polymyxa graminis and Indian peanut clump virus (IPCV) infection on various monocotyledonous crops and groundnut during the rainy season. Plant Pathol. 51:546-560.

7. Gates, L. F. 1975. Influence of sowing dates, soil amendments, and cultivars on Wheat spindle streak mosaic in winter wheat. Can. J. Plant Sci. 55:891-895.

8. Hunger, R. M., Armitage, C. R., and Sherwood, J. L. 1989. Effects of Wheat soilborne mosaic virus on hard red winter wheat. Plant Dis. 73:949-952.

9. Miller, N. R., Bergstrom, G. C., and Sorrells, M. E. 1992. Effect of Wheat spindle streak mosaic virus on yield of winter wheat in New York. Phytopathology 82:852-857.

10. Nolt, B. L., Romaine, C. P., Smith, S. H., and Cole, H. 1981. Further evidence for the association of Polymyxa graminis with the transmission of Wheat spindle streak mosaic virus. Phytopathology 71:1269-1271.

11. Rao, A. S., and Brakke, M. K. 1969. Relation of Soil-borne wheat mosaic virus and its fungal vector Polymyxa graminis. Phytopathology 59:581-587.

12. Slykhuis, J. T. 1974. Differentiation of transmission and incubation temperatures for Wheat spindle streak mosaic virus. Phytopathology 64:554557.

13. Slykhuis, J. T., and Barr, D. J. S. 1978. Confirmation of Polymyxa graminis as a vector of Wheat spindle streak mosaic virus. Phytopathology 68:639644. 